\title{
MENINGKATKAN KETERAMPILAN BERBICARA SISWA DENGAN MENGGUNAKAN METODE PERCAKAPAN PADA PELAJARAN BAHASA INDONESIA DI KELAS IX-3 SMP NEGERI 4 PERCUT SEI TUAN KABUPATEN DELI SERDANG T.A 2017/2018
}

\author{
Nilawati \\ SMP Negeri 4 Percut Sei Tuan
}

\begin{abstract}
Abstrak
Penelitian ini dilaksanakan di SMP Negeri 4 Percut Sei Tuan Kabupaten Deli Serdang, dengan menggunakan Metode Percakapan dengan sasaran utama untuk mengetahui peningkatan keterampilan berbicara pada pelajaran Bahasa Indonesia di Kelas IX-3 SMP Negeri 4 Percut Sei Tuan Kabupaten Deli Serdang. Masalah yang dihadapi dalam penelitian ini adalah masalah rendahnya keterampilan siswa dalam berbicara pada materi memperagakan teks percakapan di telepon di Kelas IX-3 SMP Negeri 4 Percut Sei Tuan Kabupaten Deli Serdang. Rumusan masalah dalam penelitian ini apakah dengan penggunaan Metode Percakapan dapat meningkatkan keterampilan berbicara siswa pada materi pokok memperagakan teks percakapan di telepon. Tujuan penelitian ini adalah untuk mengetahui peningkatan keterampilan berbicara siswa dengan menggunakan Metode Percakapan. Untuk memperoleh data dalam penelitian ini maka peneliti melakukan observasi dan tes. Adapun observasi yang dilakukan meliputi observasi guru dan siswa. Sedangkan tes dilaksanakan pada pre tes, siklus I dan II. Dari hasil observasi yang diperoleh dari 20 orang siswa pada tes awal (pre tes) hanya terdapat 5 siswa yang terampil berbicara dengan persentase $25 \%$. Nilai rata-rata yang diperoleh siswa adalah 57,75. Maka dilakukan siklus I untuk melihat peningkatan keterampilan berbicara siswa. Dari siklus I diperoleh hasil 13 siswa yang terampil berbicara dengan persentase $65 \%$ dan nilai ratarata yang diperoleh sebesar 71,7. Pada siklus I keterampilan berbicara siswa mengalami peningkatan sebesar $40 \%$ dibandingkan pada pre tes. Namun hasil tersebut belum mencapai target yang diharapkan oleh peneliti yaitu siswa yang terampil berbicara mencapai $80 \%$. Selanjutnya peneliti melakukan siklus II agar hasil yang diperoleh siswa sesuai dengan yang diharapkan. Dari siklus II diperoleh hasil 18 siswa dinyatakan terampi berbicara dengan persentase $90 \%$ dan nilai rata-rata yang diperoleh siswa 83. Dari hasil tersebut dapat disimpulkan bahwa pembelajaran dengan menggunakan Metode Percakapan dapat meningkatkan keterampilan berbicara siswa pada pelajaran Bahasa Indonesia di Kelas IX-3 SMP Negeri 4 Percut Sei Tuan Kabupaten Deli Serdang. Dari hasil temuan peneliti di atas dapat disimpulkan bahwa hipotesis yang diajukan yaitu dengan menggunakan Metode percakapan dapat meningkatkan keterampilan berbicara siswa pada pelajaran Bahasa Indonesia di Kelas IX-3 SMP Negeri 4 Percut Sei Tuan Kabupaten Deli Serdang T.A 2017/2018 dapat diterima.
\end{abstract}

Kata Kunci: Kemampuan Berbicara, Percakapan

\section{PENDAHULUAN}

Bahasa adalah alat komunikasi utama dalam kehidupan. Kemampuan berbahasa itu pada mulanya dikuasai manusia tanpa disadari. Selanjutnya terjadi perkembangan perbendaharaan kata yang digunakan dalam berbahasa. Perkembangan itu terjadi melalui belajar sesuai dengan pengalaman yang dilalui setiap individu. Akhirnya pengalaman itu terlihat dalam suatu aktivitas 
kominikasi. Untuk keefektifan komunikasi itu pulalah diperlukan keterampilan berbahasa, baik lisan maupun tulisan.

Bahasa Indonesia sebagai salah satu bidang studi yang memiliki tujuan membekali siswa untuk mengembangkan bahasa di samping aspek penalaran dan hafalan sehingga pengetahuan dan informasi yang diterima siswa sebatas produk bahasa dan sastra. Padahal dalam proses belajar mengajar keterlibatan siswa secara totalitas, artinya melibatkan pikiran, penglihatan, pendengaran, dan keterampilan. Jadi dalam proses belajar mengajar, seorang guru harus mengajak siswa untuk mendegarkan, menyajikan teknik yang dapat dilihat, memberikan kesempatan untuk menulis dan mengajukan pertanyaan atau tanggapan, sehingga terjadi percakapan (dialog) kreatif yang menunjukkan proses belajar mengajar yang interaktif.

Bahasa Indonesia yang terintegrasi dalam empat kemampuan yang harus dikuasai siswa dalam berkomunikasi baik secara lisan, yaitu : mendengarkan, dan berbicara, maupun tulisan yaitu : membaca dan menulis. Salah satu keterampilan yang harus dimiliki oleh siswa dalam belajar bahasa adalah keterampilan berbicara dalam Bahasa Indonesia dengan baik dan benar. Menurut Adil (dalam Tim Dosen, 2008 : 14 ) "Berbicara pada umumnya dapat diartikan sebagai suatu kegiatan menyampaikan maksud, ide, perasaan, dan isi hati kepada orang lain yang menggunakan bahasa lisan sehingga maksud tesebut dapat dipahami oleh orang lain". Keterampilan berbicara sangat penting dikuasai oleh siswa karena melalui berbicara siswa dapat mengekspresikan dan menyampaikan pikiran atau gagasan terhadap orang lain. Bebricara secara umum dapat diartikan sebagai suatu pencapaian maksud ( ide, pikiran, isi hati ) seseorang kepada orang lain dengan menggunakan bahasa lisan sehingga maksud tersebut mudah dipahami oleh orang lain. Bahasa lisan adalah alat komunikasi berupa simbol yang dihasilkan oleh alat ucap manusia. Jadi berbicara itu adalah kemampuan mengucapkan bunyi-bunyi artikulasi atau kata untuk mengekspresikan, menyatakan serta menyampaikan pikiran, gagasan, dan perasaan.

Berdasarkan hasil wawancara dengan wali KELAS IX-3 SMP NEGERI 4 PERCUT SEI TUAN KABUPATEN DELI SERDANG, ditemukan beberapa masalah yang menyebabkan rendahnya keterampilan berbicara siswa. Masalah yang menyebabkan rendahnya keterampilan berbicara siswa dikarena kurangnya minat siswa dalam mengikuti pelajaran Bahasa Indonesia dengan alasan Bahasa Indonesia merupakan bahasa sehari-hari sehingga mereka menganggap sepele pada pelajaran tersebut. Selain itu guru masih menggunakan metode ceramah dalam mengajarkan pelajaran Bahasa Indonesia sehingga menyebabkan siswa merasa jenuh. Rendahnya keterampilan berbicara siswa terlihat dari kurangnya perbendaharaan kosakata yang dimiliki siswa saat siswa diminta oleh guru untuk mengemukakan pendapatnya mengenai masalah yang diberikan oleh guru. Saat 
mengemukakan pendapatnya siswa merasa kurang percaya diri karena siswa masih cenderung menggunakan bahasa yang tidak baku atau bahasa daerah (saat ingin mengucapkan kata "sering" siswa tersebut mengucapkan kata "lalap") dan masih banyak lagi.

Oleh sebab itu guru harus menggunakan metode yang bervariasi dan menciptakan proses belajar sambil bermain dan suasana kelas yang menyenangkan, sehingga siswa merasa pelajaran Bahasa Indonesia itu tidak sulit dan dapat meningkatkan keterampilan berbicara siswa.

Dalam kegiatannya, keterampilan berbicara dapat dilihat dari berbagai contoh seperti (1) bercerita, (2) berdialog (percakapan), (3) berpidato, (4) berdiskusi, (5) protokol (pembawa acara / MC). Agar kegiatan berbicara ini dapat dikuasai dengan baik sebagai suatu keterampilan, siswa dapat mempraktikkannya untuk dapat meningkatkan keterampilan berbicara siswa dalam pelajaran Bahasa Indonesia.

Dari kenyataan di atas, salah satu usaha yang dilakukan Penulis untuk menanggulangi masalah tersebut adalah dengan menerapkan metode percakapan.

Metode percakapan pada umumnya kegiatan berbicara dua arah, maksudnya para partisipan saling berbicara, bertanya jawab, menanggapi mitra berbicara. Menurut Hildebrand (dalam Moeslichatoen 2004:26) "metode percakapan berarti cara untuk saling mengkomunikasikan pikiran dan perasaan secara verbal". Percakapan dapat juga diartikan sebagai pembicaraan, perundingan, satuan interaksi bahasa antara dua pembicara atau lebih. Dalam pengertian khusus metode percakapan merupakan percakapan yang terjadi antar pelaku dalam suatu drama. Dengan menggunakan metode percakapan yang dilakukan dengan teman diharapkan siswa lebih aktif dalam melakukan keterampilan berbicara.

Atas dasar inilah penulis tertarik untuk melakukan penelitian mengenai kemampuan berbicara siswa dengan memilih judul "Meningkatkan Keterampilan Berbicara Siswa Dengan Menggunakan Metode Percakapan Pada Pelajaran Bahasa Indonesia Di Kelas IX-3 SMP Negeri 4 Percut Sei Tuan Kabupaten Deli Serdang T.A 2017/2018.

Menurut Tarigan (2008:1) "keterampilan adalah kecakapan untuk mengerjakan tugas atau usaha setiap individu untuk mengidentifikasi masalah, berpikir dan menggunakan kebijakan yang ada pada diri mereka". Sedangkan menurut Soemardji (1992:6) pengertian keterampilan adalah "usaha untuk memperoleh cekat, cepat, dan tepat dalam menghadapi permasalahan belajar". Selanjutnya menurut Syah (2004:24) bahwa keterampilan adalah "kegiatan yang berhubungan dengan urat-urat syaraf dan otot-otot yang lazimnya tampak dalam kegiatan jasmaniah seperti menulis, mengetik, olahraga, dan sebagainya". 
Dari pendapat di atas maka disimpulkan keterampilan adalah usaha untuk berpikir dan mengembangkan potensinya dengan baik dan semenarik mungkin yang ada pada diri siswa.

Menurut Hildebrand (dalam Moeslichatoen, 2004:26) "berbicara adalah saling mengkomunikasikan pikiran dan perasaan secara verbal atau mewujudkan kemampuan bahasa reseptif dan bahasa ekspresif". Sedangkan menurut Adil (dalam Tim Dosen, 2012:29) "berbicara adalah suatu kegiatan menyampaikan maksud (ide, pikiran, perasaan, isi hati) kepada orang lain dengan menggunakan bahasa lisan sehingga maksud tersebut dapat dipahami oleh orang lain".

Menurut Tarigan (2007:4) keterampilan berbicara adalah "kecakapan untuk mengucapkan bunyi-bunyi artikulasi atau kata-kata untuk mengekspresikan, menyatakan serta menyampaikan pikiran, gagasan, dan perasaan".

Keterampilan berbicara pada hakikatnya berhubungan erat dengan perkembangan kosa kata yang diperoleh oleh siswa melalui kegiatan menyimak dan membaca. Kebelum matangan dalam perkembangan bahasa juga merupakan suatu keterlambatan dalam kegiatan berbahasa. Dan perlu disadari bahwa keterampilan yang diperlukan bagi kegiatan berbicara yang efektif banyak persamaannya dengan yang dibutuhkan bagi komunikasi efektif dalam keterampilan berbahasa lainnya.

\section{METODE PENELITIAN}

Jenis penelitian ini adalah penelitian tindakan kelas. Tindakan yang dilakukan adalah dengan menggunakan metode percakapan yang bertujuan untuk memperbaiki proses pembelajaran dalam meningkatkan keterampilan berbicara siswa dalam pelajaran Bahasa Indonesia dengan materi pokok Memperagakan Teks Percakapan Telepon di Kelas IX-3 SMP Negeri 4 Percut Sei Tuan Kabupaten Deli Serdangt.A 2017/2018. Lokasi penelitian dilakukan di Kelas IX-3 SMP Negeri 4 Percut Sei Tuan Kabupaten Deli Serdang Tahun Ajaran 2017/2018. Subjek dalam penelitian ini adalah seluruh siswa Kelas IX-3 SMP Negeri 4 Percut Sei Tuan Kabupaten Deli Serdang T.A 2017/2018 yang terdiri dari 20 orang siswa, dengan jumlah siswa laki - laki 8 orang dan siswa perempuan 12 orang. Objek penelitian yaitu penggunaan metode percakapan dalam pelajaran Bahasa Indonesia.

Desain penelitian ini menggunakan desain Kemis dan Mc. Taggart yang digambarkan oleh Aqib ( $2009: 45$ ). 


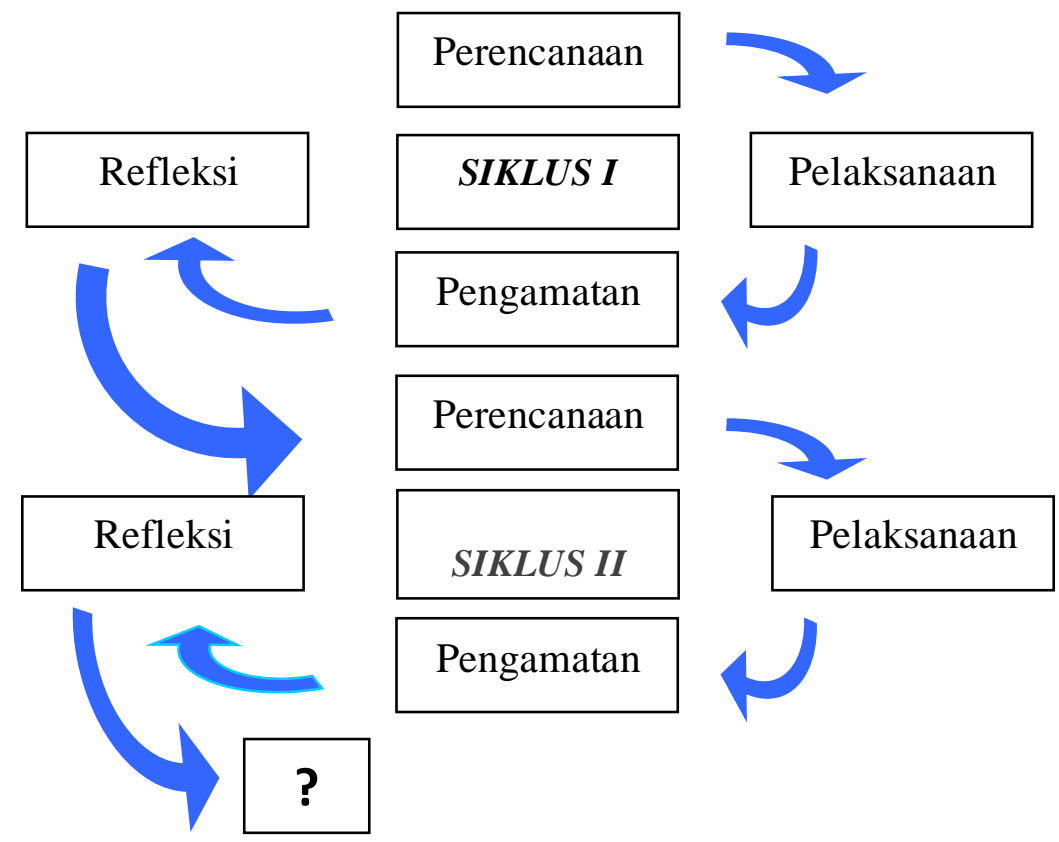

\section{Gambar 1 : Skema Pelaksanaan Tindakan Kelas}

\section{HASIL DAN PEMBAHASAN PENELITIAN}

\section{Hasil Tindakan Siklus I}

Di dapat bahwa kemampuan siswa pada materi pokok memperagakan teks percakapan di telepon, meningkat dari hasil tes sebelumnya yaitu terdapat 15 orang peserta didik yang tuntas dengan persentase sebesar $75 \%$ dan nilai rata-rata sebesar 71 . Sementara siswa yang belum tuntas sebesar 5 peserta didik dengan persentase sebesar $25 \%$ dan nilai rata-rata 53.

Dengan demikian perolehan nilai tes awal sampai dengan siklus I terjadi perubahan yang signifikan. Pada tes awal hanya ada 5 peserta didik yang tuntas dengan persentase $25 \%$ dan nilai ratarata 53 , dan meningkat pada siklus I dengan 15 peserta didik yang tuntas dengan persentase $75 \%$ dan nilai rata-rata71.

Tabel 8 Deskripsi Tes Keterampilan Berbicara Siswa Pada Pre Test dan Siklus I

\begin{tabular}{|l|l|l|l|}
\hline No. & $\begin{array}{l}\text { Pencapaian Ketuntasan } \\
\text { Keterampilan Berbicara }\end{array}$ & $\begin{array}{l}\text { Tes awal } \\
\text { (pre test) }\end{array}$ & Siklus I \\
\hline 1. & Nilai Rata-rata & 53 & 71 \\
\hline 2. & Jumlah siswa yang tidak tuntas & 15 & 5 \\
\hline 3. & Jumlah siswa yang tuntas & 5 & 15 \\
\hline 4. & Persentase Ketuntasan & $25 \%$ & $75 \%$ \\
\hline
\end{tabular}


Dari keseluruhan siswa terdapat 5 orang siswa mendapatkan nilai $<70$ dan 15 siswa mendapatkan nilai $>70$. Sehingga dari tingkat penguasaan yang diperoleh siswa secara keseluruhan dapat diperoleh ketuntasan belajar dengan menggunakan rumus sebagai berikut:

$$
\begin{gathered}
f \\
P=-\times 100 \% \\
n \\
15 \\
P=-\times 100 \% \\
20 \\
P=75 \%
\end{gathered}
$$

Berdasarkan hasil perhitungan maka dapat diketahui ketuntasan belajar siswa sebesar $75 \%$ atau 15 siswa dan berdasarkan tes yang diberikan sebelumnya terjadi peningkatan sebesar $50 \%$. Meskipun demikian keberhasilan proses belajar mengajar pada siklus I belum sesuai dengan target nilai yang akan dicapai yaitu sebesar $80 \%$ siswa tuntas dalam belajar. Sehingga perlu diadakan kembali perbaikan pembelajaran yang memungkinkan dapat memaksimalkan hasil belajar siswa, oleh karena itu penelitian dilanjutkan pada siklus II.

\section{Hasil Tindakan siklus II}

Hasil yaitu bahwa kemampuan siswa pada materi pokok memperagakan teks percakapan di telepon, meningkat dari hasil tes sebelumnya yaitu terdapat 18 orang peserta didik yang tuntas dengan persentase sebesar $90 \%$ dan nilai rata-rata sebesar 83 . Sementara siswa yang belum tuntas sebesar 2 peserta didik dengan persentase sebesar $10 \%$.

Dengan demikian perolehan nilai pada siklus I sampai dengan siklus II terjadi perubahan yang signifikan. Pada siklus I hanya ada 15 peserta didik yang tuntas dengan persentase $75 \%$ dan nilai ratarata 71 , dan meningkat pada siklus II dengan 18 peserta didik yang tuntas dengan persentase $90 \%$ dan nilai rata-rata77,5. 
Tabel 13 Deskripsi Tes Keterampilan Berbicara Siswa Pada Siklus I dan Siklus II

\begin{tabular}{|l|l|l|l|}
\hline No. & $\begin{array}{l}\text { Pencapaian Tes Keterampilan } \\
\text { Berbicara Siswa }\end{array}$ & Siklus I & Siklus II \\
\hline 1. & Nilai Rata-rata & 71 & 77,5 \\
\hline 2. & Jumlah siswa yang tuntas & 15 & 18 \\
\hline 3. & Persentase Ketuntasan & $75 \%$ & $90 \%$ \\
\hline
\end{tabular}

Dari keseluruhan siswa terdapat 2 orang siswa mendapatkan nilai $<70$ dan 18 siswa mendapatkan nilai $>70$. Sehingga dari tingkat penguasaan yang diperoleh siswa secara keseluruhan dapat diperoleh ketuntasan belajar dengan menggunakan rumus sebagai berikut:

$$
\begin{gathered}
f \\
P=-\times 100 \%
\end{gathered}
$$

$n$

$$
P=90 \%
$$

\section{Temuan Penelitian}

Faktor penghambat dalam penelitian ini adalah belum siapnya siswa dalam menghadapi situasi pembelajaran yang baru yang diberikan oleh peneliti sehingga siswa kurang berani menjawab dan bertanya. Siswa tidak mengerti bagaimana melakukan percakapan dengan baik dan menggunakan Bahasa Indonesia yang sesuai dengan Ejaan Yang Disempurnakan (EYD) hal ini dikarenakan masih seringnya siswa menggunakan bahasa daerah dalam kehidupan sehari-hari mereka. Selain itu, faktor lain berasal dari peneliti karena kurang siap menghadapi situasi di dalam kelas.

Sedangkan faktor pendukung selama penelitian ini adalah siswa cepat beradaptasi dengan situasi pembelajaran yang baru diberikan oleh peneliti, siswa sangat antusias dalam melakukan pembelajaran dan sangat senang belajar dengan memahami materi yang diperagakan dengan percakapan. Sehingga siswa menjadi semangat dalam proses pembelajaran.

Dari hasil temuan dapat disimpulkan bahwa hipotesis yang diajukan oleh peneliti yaitu dengan menggunakan Metode Percakapan pada pelajaran Bahasa Indonesia dapat meningkatkan keterampilan berbicara siswa pada materi pokok memperagakan teks percakapan di telepondi KELAS IX-3 SMP NEGERI 4 PERCUT SEI TUAN KABUPATEN DELI SERDANG T.A 2017/2018. 


\section{PEMBAHASAN PENEMUAN PENELITIAN}

Pembelajaran pada siklus I diberikan berupa pembelajaran dengan menggunakan Metode Percakapan. Dan hasil yang didapat pada siklus I setelah diberikan postes terdapat $75 \%$ atau 15 orang siswa telah mencapai ketuntasan belajar. Namun 25\% atau 5 orang siswa lainnya belum mencapai ketuntasan belajar. Dan hasil observasi keterampilan berbicara siswa pada siklus I terdapat $65 \%$ atau 13 siswa yang terampil berbicara dan $35 \%$ atau 7 siswa yang belum terampil berbicara. Namun ketuntasan belajar dan keterampilan berbicara yang diperoleh siswa masih rendah. Siklus II dilaksanakan sesuai dengan pengembangan pada pembelajaran siklus I. Sehingga hasil yang diperoleh pada siklus I| 90\% atau 18 orang siswa telah tuntas dalam belajarnya dan terampil berbicara, dan $10 \%$ atau 2 orang siswa belum mencapai ketuntasan dalam belajar dan belum terampil berbicara.

Secara klasikal ketuntasan belajar siswa adalah 90\% sehingga secara klasikal telah dapat mencapai ketuntasan. Hasil observasi siswa dan guru pada siklus I mengalami peningkatan pada siklus II. Berdasarkan keterangan diatas dapat disimpulkan aktifitas yang terjadi didalam kelas meningkat sehingga meningkatkan hasil belajar yang diperoleh siswa.

Setelah dilakukan tindakan pembelajaran dengan menggunakan Metode percakapan diperoleh peningkatan hasil belajar sebesar $90 \%$ atau 18 orang telah mencapai ketuntasan dalam belajarnya. Hal ini berarti ketuntasan belajar siswa telah tercapai. Oleh karena itu, Metode percakapan efektif digunakan dalam meningkatkan keterampilan berbicara siswa.

Dengan peningkatan tes keterampilan berbicara siswa yang diperoleh siswa dari mulai tes awal atau Pre test, siklus I dan sampai dengan dilakukannya siklus II ini, telah terjadi peningkatan yang cukup signifikan yaitu sebesar $50 \%$ yang pada test awal siswa hanya memperoleh nilai rata - rata 53 dan pada siklus I rata - rata nilai yang diperoleh siswa adalah 71 dan pada siklus II perolehan nilai rata - rata siswa meningkat menjadi 77,5. Peneliti merasa telah cukup memenuhi ketuntasan klasikal sesuai dengan harapan peneliti.

Pembelajaran pada siklus I diberikan berupa pembelajaran dengan menggunakan Metode percakapan. Dan hasil yang didapat pada siklus I setelah diberikan postes terdapat $75 \%$ atau 15 orang siswa telah mencapai ketuntasan belajar. Namun $25 \%$ atau 5 orang siswa lainnya belum mencapai ketuntasan belajar. Dari hasil yang diperoleh siswa maka ketuntasan belajar siswa secara klasikal adalah 75\%. Namun ketuntasan belajar yang diperoleh siswa masih rendah. Siklus II dilaksanakan sesuai dengan pengembangan pada pembelajaran siklus I. Sehingga hasil yang diperoleh pada siklus II 90\% atau 18 orang siswa telah tuntas dalam belajarnya, dan 10\% atau 2 orang siswa belum mencapai ketuntasan dalam belajar. 


\section{KESIMPULAN}

Berdasarkan penelitian yang telah disajikan dalam temuan maka dapat diambil kesimpulan bahwa :

1. Dari hasil pelaksanaan siklus I, yang kemudian dilanjutkan dengan pemberian post test dan observasi maka diperoleh tingkat ketuntasan belajar siswa sebesar $75 \%$ atau 15 peserta didik yang tuntas dan observasi keterampilan berbicara siswa secara klasikal sebesar $65 \%$ atau 13 peserta didik terampil berbicara.

2. Dari hasil pelaksanaan siklus II, diperoleh tingkat ketuntasan belajar siswa sebesar $90 \%$ atau 18 peserta didik tuntas dalam belajar dan observasi keterampilan berbicara siswa secara klasikal sebesar $90 \%$ atau 18 peserta didik terampil berbicara.

3. Dari hasil pelaksanaan siklus I dan II maka diperoleh peningkatan sebesar $25 \%$.

Dengan demikian dapat disimpulkan bahwa penggunaan Metode Percakapan dapat meningkatkan keterampilan berbicara siswa pada pelajaran Bahasa Indonesia Kelas IX-3 SMP Negeri 4 Percut Sei Tuan Kabupaten Deli Serdang T.A 2017/2018.

\section{DAFTAR PUSTAKA}

Aqib, (2009). Penelitian Tindakan Kelas. Bandung : Yrama Widya.

Moeslichatoen R. 2004. Metode Pengajaran. Jakarta : Rineka Cipta.

Syah, M. 2004. Kompeten Berbahasa Indonesia. Jakarta : Rineka Cipta.

Soemardji. 1992. Tata Bahasa Baku Bahasa Indonesia. Jakarta : Balai Pustaka.

Tarigan, Guntur, Henry. 2008. Pengajaran Pragmatik. Bandung : Angkasa.

Tim Dosen. 2008. Peningkatan Keterampilan Berbahasa Indonesia. Medan : FIP-UNIMED. 